\title{
NOTAS COMPARATIVAS SOBRE A DOMESTICAÇÃO DOS BRANCOS ${ }^{1}$
}

\author{
RODRIGO ROSSI MORA BRUSCO \\ USP, BRASIL
}

\begin{abstract}
RESUMO: Este artigo compara uma série de etnografias que descrevem processos de aparentamento entre índios e não indios nas terras baixas sul-americanas. Sugere-se que esses exemplos de "domesticação dos brancos", tais como aqui chamados, são um caso do fenômeno mais geral de amansamento de estrangeiros e inimigos indígenas. Em todos os casos, visa-se "acostumar" um Outro e, nele, causar uma alotransformação, reduzindo assim sua alteridade constitutiva e possibilitando, em última instância, o parentesco. $O$ artigo ainda discute duas formas de classificação dos não índios nas terras baixas sul-americanas e a relação da "domesticação dos brancos" com outras duas sínteses sobre a América indígena, aquela da "predação familiarizante" (Carlos Fausto) e aquela da "civilização do outro" (Fernando Santos-Granero). Ao final, traça-se uma conexão com a proposta de trabalho de Marcio Goldman a favor de uma "teoria etnográfica da contramestiçagem".
\end{abstract}

PALAVRAS-CHAVE: Parentesco; domesticação dos brancos; transformações indígenas; terras baixas sul-americanas.

\begin{abstract}
The article compares a set of ethnographies that describe kinship processes between indians and nonindians in Lowland South America. These examples of "domestication of whites" are a version of the widespread phenomenon of taming of indigenous strangers and enemies. In all the examples, the aim is to "accustom" the Other and prompt on him/her an alotransformation, reducing his/her constitutive alterity and thus enabling kinship. The article also turns itself to two forms of classification of the whites in indigenous America, and to the comparison with two other regional synthesis, that of "familiarizing predation" (Carlos Fausto) and that of "civilizing the Other" (Fernando Santos-Granero). At the end, the article draws on a connection with Goldman's proposal of an "ethnographic theory of counter-mestiçagem".
\end{abstract}

KEYWORDS: Kinship; domestication of whites; indigenous transformations; Lowland South America.

\footnotetext{
${ }^{1}$ Este texto é uma versão modificada de um dos capítulos de minha dissertação de mestrado. Agradeço à orientadora do trabalho, Marina Vanzolini, bem como aos participantes da banca de defesa, Valeria Macedo, Renato Sztutman e Eduardo Nunes. Agradeço ainda à Fundação de Amparo à Pesquisa de São Paulo, processo n ${ }^{\circ}$ 2016/03139-8, pelo financiamento que permitiu a concepção e elaboração deste artigo. 2 Doutorando em Antropologia Social (Universidade de São Paulo, Brasil). E-mail: rodrigorossi_10@hotmail.com
} 


\section{Introdução}

Diz-se que as tentativas de colonização do Brasil pelos franceses contaram com uma figura muito interessante: os chamados truchements, jovens que viviam anos junto aos índios para posteriormente tornaremse intérpretes dos colonizadores. O próprio Michel de Montaigne teria se servido dos relatos de um desses rapazes, que haveria passado de "dez a doze anos" junto aos índios, para escrever "Dos Canibais". Afirma-se que esses truchements aprendiam a língua dos indígenas, seus costumes, participavam de rituais antropofágicos e se casavam com mulheres indígenas. A despeito de serem uma figura importante para 0 empreendimento colonial francês, nem todos os franceses tinham visões positivas sobre esses rapazes, uma vez que pareciam tornar-se "selvagens" (cf. LÉRY, [1 578] 2009, p. 115).

Mais de um século mais tarde, o ouvidor da capitania do Rio Negro, Francisco Xavier Ribeiro de Sampaio, comenta em seu diário que a política pombalina de incentivo aos casamentos entre homens militares e mulheres indígenas não estava surtindo o efeito desejado. Não porque as uniões não estavam ocorrendo, mas porque eram antes os "civilizados" que estavam se tornando "gentios" através desses casamentos, do que o contrário (cf. ANDRELLO, 2006).

A milhares de quilômetros de distância, no Chaco argentino, Jorge Luís Borges ([1949] 2008) relata que sua própria mãe frequentava uma feira, ao final do século XIX, quando se deparou com uma índia de cabelos louros. Conforme veio a saber, tratava-se de uma mulher inglesa que fora capturada anos antes pelos índios, vindo a se casar com um chefe e a se tornar mãe de crianças indígenas. Abismada com o fato, a mãe de Borges tenta incentivar a mulher a abandonar, junto a seus filhos, a vida entre seus captores. Para sua surpresa, recebe da índia loura uma resposta negativa.

Tais histórias de casamentos entre índios e brancos ${ }^{3}$ não são restritas ao passado. Por todas as terras baixas sul-americanas, encontramos relatos contemporâneos sobre fatos semelhantes. Índios que passam um período vivendo em alguma cidade e acabam ali se casando com um não indígena. Brancos forasteiros que são levados a viver nas aldeias e são, pelo casamento, incorporados às redes do parentesco indígena. Índios expulsos da própria aldeia por resolverem se casar com um branco. Casamentos sucessivos entre populações indígenas e não indígenas vizinhas. Os exemplos abundam e grande parte dos etnógrafos que trabalham com os povos indígenas das terras baixas sul-americanas tem ao menos um relato desse tipo para compartilhar.

Não dispúnhamos, no entanto, de nenhuma análise comparativa antropológica que procurasse dar conta desses fenômenos. Não que

\footnotetext{
${ }^{3}$ Por todo este trabalho o conceito de "branco" é utilizado intercambiavelmente com aqueles de "não índio" e "não indígena", em conformidade com o uso corrente do termo pela imensa maioria dos povos indígenas no Brasil. Isso indica que "branco" não tem um sentido racial - trata-se de um termo utilizado pelos próprios indígenas para se referirem aos descendentes daqueles que não estavam no continente americano antes da chegada dos europeus. Volto a este tema na seção final.
} 
faltem interpretações etnográficas sobre casamentos entre brancos e índios, mas nenhum autor havia se dedicado a comparar esses casos. A única exceção que pude encontrar na literatura antropológica é o trabalho de José Kelly (2016), no qual o autor elabora uma teoria da "antimestiçagem" ameríndia a partir de um sobrevoo comparativo de amplo alcance. Discutindo brevemente o trabalho de Eduardo Nunes (2012), Kelly afirma que suas conclusões deveriam ser também aplicadas aos matrimônios entre brancos e índios: os casamentos com brancos, segundo sua análise, seriam análogos a outras relações com não indígenas, tendo por efeito aquilo que ficou conhecido na literatura especializada como "virar branco". Em linhas gerais, as interações com o mundo dos brancos teriam por efeito uma autotransformação dos sujeitos indígenas, conceitualizados como pessoas duais formadas por duas "metades" (branca e indígena) que podem ser contextualmente elicitadas e eclipsadas. Kelly (2016) não está só neste tipo de interpretação: além de Eduardo Nunes (2012) em seu trabalho sobre os Karajá, também Cristiane Lasmar (2005) e Amanda Migliora (2014), para citarmos apenas dois exemplos, interpretaram os casamentos com brancos a partir deste modelo de "devir-outro", forjado inicialmente para dar conta dos efeitos dos rituais e do xamanismo nas terras baixas sulamericanas.

Os exemplos que abrem este trabalho, contudo, parecem colocar em cena outro problema: não tanto uma transformação parcial e contextual de índios em brancos, mas ao contrário, uma transformação de brancos em índios através do matrimônio. Como procurarei demonstrar, esse fenômeno é amplamente disseminado pelas terras baixas sul-americanas, não se limitando ao matrimônio. A ele dou o nome de domesticação dos brancos.

\section{O caso tupi guarani}

A transformação de brancos em índios pelo casamento foi um dos problemas a que me voltei em minha dissertação de mestrado (BRUSCO, 2018). Procurei ali preencher a lacuna etnológica notada acima - a falta de um trabalho comparativo que procurasse comparar análises etnográficas sobre casamentos entre índios e não índios. Ainda que a dissertação seja bibliográfica, foi uma curta experiência de campo que me motivou a abordar o tema.

Refiro-me a minha estadia entre os Tupi Guarani da Terra Indígena Itaoca, em Mongaguá (SP). Notei em campo algo que a olhos euroamericanos soaria como uma confusão classificatória: um sujeito podia se identificar como "Tupi Guarani verdadeiro" e, logo em seguida, me contar que tinha nascido "caiçara". De modo análogo, uma pessoa poderia se referir a outra como "Tupi Guarani" e, em outro contexto, como "branca". Logo de saída ficou claro a mim que os objetos dessa aparente "confusão" classificatória eram pessoas que, tendo uma origem não indígena, haviam se casado com algum indígena tupi guarani. 
Os Tupi Guarani são um povo indígena que vive espalhado por diversas Terras Indígenas no Estado de São Paulo. Anteriormente identificados como "Guarani Nhandeva", resolveram recentemente mudar sua autodenominação, por considerarem que são o resultado de intercasamentos, ocorridos no passado, entre os Guarani que chegaram ao litoral paulista no século XIX e os povos Tupi que ali já se encontravam desde a invasão europeia (cf. MAINARDI, 2010; DANAGA, 2016). Em conformidade com aquilo que observei em campo, a literatura especializada aponta que os Tupi Guarani têm se casado com não indígenas há algum tempo: Schaden ([1954] 1974) já apontava uma tendência aos casamentos com "regionais" pelos Guarani Nhandeva, fato também ressaltado por Mauro Cherobim (1986). Mais recentemente, as antropólogas que se dedicaram a etnografar esse povo também registraram alguns casamentos com brancos (cf. MAINARDI 2015; ALMEIDA, 2016; DANAGA, 2016).

Por motivos que não terei como abordar aqui, meu trabalho de campo junto aos Tupi Guarani não pôde ter prosseguimento. As análises etnográficas disponíveis sobre este povo, no entanto, revelam uma curiosa e interessante característica, semelhante àquela que notei em campo: como afirmam Camila Mainardi (2015), Lígia Rodrigues de Almeida (2016) e Amanda Danaga (2016), os Tupi Guarani insistem que seus cônjuges não indígenas se tornem "índios" conforme compartilhem comidas e substâncias. Como afirma Pitotó, interlocutor de Mainardi (2015, p. 80), se os cônjuges não indígenas "se acostumam" ao modo de viver tupi guarani, eles se tornam "que nem índio". Da mesma maneira, interlocutores de Almeida (2016, p. 145; grifos suprimidos) afirmam que "se casou com índio, vira índio também", já que essas pessoas passam a viver "mesmo como índio". Toninho Awá, cacique da aldeia Ywyty Guaçú que teve algumas de suas falas registradas na tese de Amanda Danaga, vai ainda mais longe, ao afirmar que conheceu "brancos que são até mais índios que muitos índios" (DANAGA, 2016, p. 58).

Face a estes exemplos, parece que os Tupi Guarani elaboram à sua maneira o problema notado no início deste trabalho: a possibilidade de que brancos sejam transformados em índios mediante o casamento. $O$ que isto implica? Seria este fenômeno disseminado pelas terras baixas sul-americanas? Como compreendê-lo à luz das teorias do "virar branco"? Comecemos por exemplos que não envolvem os brancos.

\section{O amansamento de estrangeiros}

A tese de doutorado de Catherine Howard (2001) oferece uma longa descrição sobre os esforços waiwai para amansar ou pacificar povos "ferozes". Após se converterem ao cristianismo, os Waiwai passaram a se interessar pelas expedições de contato a povos ditos "isolados", procurando-os para "pacificá-los" ou "acostumá-los" (-enpamnopu). As expedições em busca desses povos "não vistos" (enîhnî komo) tornaramse frequentes entre os Waiwai, de tal modo que passaram a ser um imperativo para a fundação de novos grupos locais. Segundo Howard 
(2001), um chefe deveria convencer um povo "não visto" a residir junto a si, fazendo seus novos corresidentes se acostumarem ao modo de vida "sociável" e "pacífico" dos Waiwai (expresso pelo conceito de tawake). Dispendendo cuidados como fazem a crianças e animais domésticos, os Waiwai transformavam esses povos em "plenamente humanos", o que abria a possibilidade de que alianças matrimoniais fossem estabelecidas entre pacificadores e pacificados após três ou quatro gerações. Howard (2001) cunha esse processo de "waiwai-zação", descrito pelos Waiwai a partir do verbo -enpamnopu ("amansar"), que "significa literalmente "fazer alguém se sentir acostumado"”4 (HOWARD, 2001, p. 324).

Encontramos também na região das Guianas inúmeros outros exemplos de domesticação de estrangeiros por povos indígenas. Os Aparai afirmam ter "pacificado", ou "amansado", os Wayana, com quem passaram a viver e se casar (cf. BARBOSA, 2005, 2009). Da mesma forma, a tese de Dominique Gallois (1988) descreve processos de atração e "amansamento" de estrangeiros pelos Wajãpi, que culminaram em intercasamentos. Também Grupioni (2002, p. 33) e Barbosa (2009, p. 104) relatam que os Tiriyó foram responsáveis pela "pacificação" dos Kaxuyana, com quem posteriormente passaram a se casar.

Exemplos análogos não estão restritos às Guianas. As relações entre os grupos de língua tukano oriental e seus vizinhos Maku (Hupdah) revelam um movimento semelhante. Conforme demonstra Jean Jackson (1983), os casamentos entre Tukano e $M a k u^{5}$ são rejeitados pelos primeiros, ainda que possam ocorrer - sobretudo entre homens maku e mulheres tukano. Quando acontecem, o cônjuge maku é eventualmente "assimilado" ao modo de vida tukano, de tal modo que seu passado enquanto maku é frequentemente apagado (JACKSON, 1983, p. 156). Além disso, alguns povos tukano costumam afirmar que sibs de baixa hierarquia foram um dia grupos maku acoplados a uma maloca tukano (JACKSON, 1983, p. 159). Retomando esse exemplo num trabalho comparativo, Santos-Granero (2009, p. 114) afirma que as relações entre os dois povos por vezes engendraram fenômenos de "tukanização" através dos quais "povos selvagens da floresta" foram transformados em "vizinhos civilizados". Neste sentido, Aloisio Cabalzar (2009, p. 130) apresenta um relato sobre o casamento entre um homem maku e uma mulher tuyuka, que teria dado origem a um dos sibs tuyuka de baixa hierarquia, os Miriti-tapuya. Como afirmou outrora um interlocutor, foi "assim que os Miriti-tapuya viraram gente, patrão, tornando-se genro" (apud CABALZAR, 2009, p. 130).

$\mathrm{Na}$ região do rio Madeira, diversos grupos indígenas foram no passado incorporados ao povo Mura, por meio de um processo frequentemente chamado de "murificação". Conforme aponta Marta

\footnotetext{
${ }^{4}$ São minhas todas as traduções de textos citados em línguas estrangeiras nas referências bibliográficas.

${ }^{5}$ Atualmente os Maku são referidos por distintos nomes, usualmente derivativos de "hup" (como Hupdah, Hupdeh, etc.). Estou ciente do caráter pejorativo que o etnônimo "maku" guarda, atribuído principalmente pelos povos de língua tukano oriental que habitam as margens dos grandes rios e afluentes da região (cf. LOLLI, 2016). No entanto, para não me distanciar do antigo debate sobre a distinção "Maku" vs. "índios do Rio", bem como para conservar a coletivização, assaz instrutiva, desses povos dos interflúvios pelas próprias populações de língua tukano oriental, mantenho a denominação Maku.
} 
Amoroso (1992), os cronistas oscilam entre considerar esse processo como voluntário - pessoas de povos estrangeiros que decidiram por própria conta se juntar aos Mura (incluindo, no século XIX, negros e ciganos) - ou involuntário, associado à captura de cativos nas guerras (AMOROSO, 1992, p. 308-9). Amoroso não exclui nenhuma das duas hipóteses, sugerindo que podem ter coexistido.

Deveríamos ainda mencionar o estudo comparativo de Fernando Santos-Granero (2009) sobre supostas formas indígenas de escravidão pré-colombianas. Sem adotarmos ou refutarmos suas hipóteses sobre a pertinência de falarmos em "escravidão" ameríndia, os exemplos Kalinago, Conibo, Chiriguaná, Calusa e Guiacuru discutidos por SantosGranero revelam uma mesma dinâmica: a possibilidade de incorporação de estrangeiros através de procedimentos de transformação corporal. Santos-Granero (2009) dá a este processo o nome de "civilização do outro", caracterizado pelo autor como a transformação de um cativo (ou de seus descendentes) em "parente" (ponto a que volto abaixo).

Com a breve discussão destes exemplos, notamos um fenômeno disseminado pelas terras baixas sul-americanas: a possibilidade, ainda que limitada, da transformação de estrangeiros (ou mesmo inimigos) em parentes, através da comensalidade, da consubstanciação e do casamento. Em suma, pessoas consideradas "menos-que-humanas" por um determinado grupo podem tornar-se plenamente "humanas" conforme integrem o parentesco segundo os parâmetros locais. Isso inclui, evidentemente, a transformação corporal: o aprendizado da língua, das formas corretas de se referir a parentes, a ornamentação corporal adequada, etc. Dessa maneira, é somente pelo corpo que um inimigo ou um estrangeiro pode se tornar parente, de modo análogo a como uma criança (cf. GOW, 1997) ou um animal de estimação (cf. FAUSTO, 2001) devem ser feitos plenamente humanos através do tempo. Contudo, como todos os exemplos destacam, essa transformação do outro pelo casamento raramente se completa - mesmo quando ocorre, há sempre a possibilidade de um suposto ex-estrangeiro revelar sua alteridade constitutiva em algum contexto. Algo semelhante se dá com os filhos de uniões mistas: em alguns povos afirma-se que essas crianças são plenamente humanas, em outros reitera-se seu passado alienígena. Assim, as diferenças interiorizadas pelo casamento com um estrangeiro podem ser mais ou menos apagadas, mas tendem a permanecer e fornecer identidades diferenciais ao longo de algumas gerações.

\section{O Outro como Parente}

Por nossa discussão comparativa, pareceria que o fenômeno de transformação de brancos em parentes pelos Tupi Guarani se reportaria a um processo semelhante. Com efeito, o processo de transformação de inimigos e estrangeiros em "parentes" é estendido aos não indígenas. Vejamos alguns exemplos.

José Glebson Vieira (2010) aponta, para os Potiguara da Paraíba, que alguns não indígenas, conforme passaram a viver junto aos índios, 
foram reclassificados como "sertanejos", depois como "rendeiros", posteriormente como "avilados" e, por fim, como "caboclos" (i.e., indígenas). Essa reclassificação foi possível graças ao compartilhamento de substâncias e comida e às replicações de alianças matrimoniais. Segundo Vieira (2010, p. 110-1), ao inserir os brancos nas redes de parentesco, os Potiguara procuraram, e ainda procuram, reduzir progressivamente a distância dos não indígenas, aproximando-os das convenções indígenas. Nas palavras do autor, os índios tentam dirigir aos brancos um "comportamento moralmente apropriado, traduzido na partilha, coresidência e alianças matrimoniais" (VIEIRA, 2010, p. 111). Portanto, os brancos interiorizados devem revelar pelos seus comportamentos que desejam viver como índios, traço fundamental para a possibilidade de serem reclassificados como "caboclos".

Contudo, José Glebson Vieira demonstra que a diferença dos brancos jamais é obliterada por completo. Isso pode ser percebido, em primeiro lugar, pelos filhos de uniões mistas. Segundo o autor, essas crianças são chamadas de "misturadas", e as famílias indígenas (sobretudo os avós) devem realizar grandes esforços para fazer dessas crianças pessoas plenamente indígenas, através da comensalidade, dos cuidados, afetos e da convivialidade (VIEIRA, 2010, p. 109). Evidentemente, esses esforços também precisam ser dispendidos na criação de filhos de uniões entre indígenas, porém são mais intensos nos casos das crianças "misturadas". Além disso, José Glebson Vieira (2010, p. 108) aponta que os Potiguara dão maior importância às mães indígenas que aos pais nativos, pois elas dispendem maiores cuidados na criação dos filhos e têm um sangue capaz de "tornar alguém 'mais caboclo' do que outra gerada e alimentada no corpo de uma mãe que possui 'outro sangue"'. Dessa maneira, os filhos de mães indígenas e pais brancos parecem ser mais facilmente domesticados por suas famílias.

Entre os Pataxó Hã hã hãe, os cônjuges não indígenas não são ditos serem "índios" (PEDREIRA, 2017, p. 79). No entanto, os indígenas esperam que os brancos interiorizados se comportem de modo respeitoso com eles, participem do parentesco e os ajudem nas retomadas de terra. Caso o façam, passam a ser considerados "aliados" ou "parceiros" (PEDREIRA, 2017 , p. 81). Se para parte dos Pataxó Hã hã hãe é fundamental marcar se um determinado indivíduo é ou não indígena, muitas pessoas das comunidades julgam "irrelevante" tal questão, importando-se sobretudo se o indivíduo em questão pode ser considerado um "membro da comunidade que conta com o respeito de todos" (PEDREIRA, 2017, p. 81). Seja como for, espera-se que não indígenas mantenham uma posição politicamente ativa, mas discreta, evitando assumir encargos destinados sobretudo aos indígenas (PEDREIRA, 2017, p. 79).

Os velhos pataxó hã hã hãe costumam afirmar que as uniões mistas conduzem do "primeiro" ao "segundo sangue", produzindo crianças com o sangue enfraquecido (cf. PEDREIRA, 2017, p. 24). Segundo essas mesmas pessoas, uma vez alcançado o "terceiro sangue" - representando uma criança fruto de uniões mistas na geração dos pais e dos avós -, o filho não pode mais ser considerado "indígena". No entanto, os Pataxó Hã hã hãe descartam "coletivamente" esta hipótese: muitas das famílias 
rechaçam que uma pessoa de "terceiro sangue" não seja indígena (PEDREIRA, 2017, p. 25). Mesmo assim, notamos entre esses índios que a diferença introjetada pelos cônjuges brancos não é completamente apagada: os próprios maridos e esposas não indígenas não são tornados índios e seus filhos "misturados" são diferenciados de crianças frutos de casamentos entre indígenas. A despeito dessa permanência da diferença, espera-se que os brancos interiorizados se comportem como índios, ainda que não devam assumir grande protagonismo político.

Para os Karipuna do Uaçá, ao contrário, os cônjuges não indígenas podem se tornar índios com o casamento (TASSINARI, 2003). Isso é possível pois os Karipuna procuram "aproximar" os cônjuges "de fora" com quem se casam, inserindo-os no "círculo de cooperação", baseado em trabalhos de ajuda mútua e nas festas (TASSINARI, 2003, p. 205). Como aponta Antonella Tassinari (2003, p. 204), mediante a reiteração dessas contribuições essas pessoas "de fora" são feitas "parentes" e, consequentemente, "Karipuna". Os índios afirmam que esses brancos passam a "trabalhar junto com o pessoal", inserindo-se no círculo de reciprocidade que caracteriza a boa convivência entre parentes (TASSINARI, 2003, p. 205). No entanto, como afirma a autora, esse processo de aparentamento com forasteiros não pode ser entendido sem sua contraparte: as "diferenças permanecem latentes e podem ser reafirmadas em contextos de conflito" (TASSINARI, 2003, p. 207). Desse modo, notamos mais uma vez uma "domesticação" parcial e incompleta dos brancos: eles nunca são tornados completamente índios, podendo sempre revelar sua origem externa.

Os Mura do Igapó-Açu, por sua vez, podem se casar com forasteiros brancos, e estes são investidos de "consideração", conceito mura que "indica afeto, criação e respeito" (FILENO, 2017, p. 67). Segundo Fernando Fileno, os "parentes por consideração", que eventualmente incluem brancos, são "moldados pelo costume" ao participarem dos circuitos de compartilhamento de alimentos - o que leva o autor a considerar esses esforços como uma atualização contemporânea da "murificação" (cf. supra, AMOROSO, 1992). Nas palavras do autor, tratase de um

processo de transformação sutil que passa pelo corpo. São as etiquetas respeitadas, a construção das relações, a circulação de alimentos que englobam o corpo estranho que aos poucos se entrega aos acordos, ao ritmo e aos costumes do lugar (FILENO, 2017, p. 192).

Fileno também relata a trajetória de um homem branco casado a uma mulher mura. De acordo com o autor, este homem recusava-se, de início, a comer determinadas frutas, afirmando ser "comida de macaco" (FILENO, 2017, p. 193). Após constantes repreensões de seu sogro, que o chamava de "estúpido", o homem passou a se esforçar em se alimentar dessas comidas. Ao autor, o homem afirmou: "de primeira não comia, mas agora já como" (apud FILENO, 2017, p. 193). Segundo Fileno (2017, p. 193), isso indica que o principal entrave mura à relação com a 
alteridade é a "mesa de refeições", caracterizada pelos indígenas como "o chão mesmo", onde se dispõem "diante do que havia para comer e beber". Exige-se, assim, que o branco interiorizado assuma costumes mura, dentre os quais os hábitos alimentares sejam talvez os mais importantes - afinal, produzem semelhanças entre os corpos através da comensalidade (FILENO, 2017). Entretanto, mesmo que esses brancos sejam transformados em parentes "por consideração", sua posição continua carregando incertezas e perigos (FILENO, 2017, p. 69). Os Mura têm consciência disso, mas procuram ocultar os riscos associados aos estrangeiros "através do trato diário e dos laços alargados" (FILENO, 2017, p. 69).

Também entre os Tupinambá de Olivença encontramos a importância da alimentação na transformação de brancos em índios. Segundo Susana Viegas (2012), a giroba, bebida feita a partir da mandioca, é considerada uma iguaria entre os índios e é detestada pelos não indígenas da região, por ser muito amarga e ser consumida quente. De acordo com a autora, o consumo de giroba, comparada a um alimento, permite a uma pessoa tornar-se um "índio forte" (VIECAS, 2012, p. 543). Intimamente relacionada aos cuidados cotidianos do parentesco (cf. VIEGAS, 2007), o consumo de giroba pelas crianças tupinambá é fundamental para seu crescimento enquanto indígenas, pois tem por efeito a produção de corpos índios. Conforme Viegas (2012, p. 547), a recusa no consumo de giroba pela imensa maioria dos brancos indica que seus corpos são diferentes, incapazes de apreciar a bebida - a não ser que ela esteja adocicada e gelada.

No entanto, Viegas (2012) aponta um grande número de casamentos entre brancos e índios na região. Segundo a autora, face a isso diversos cônjuges brancos julgaram importante aprender a produzir giroba e a apreciar seu sabor (VIEGAS, 2012, p. 547). Uma vez que os Tupinambá consideram que os corpos podem "mudar de acordo com o lugar e com os hábitos alimentares" (VIEGAS, 2012, p. 547), é plenamente possível que um branco passe a gostar de consumir a bebida, indicando portanto um "acoplamento de afins ao mundo emocional de seus esposos e parentes indígenas" (VIEGAS, 2012, p. 548). De acordo com Viegas (2012, p. 548), esse acoplamento foi importantíssimo no passado tupinambá: com a adversidade pela qual passaram (esgarçamento populacional, perseguições, etc.), o consumo de giroba foi fundamental para transformar "suas esposas e filhas não indígenas em 'Índias fortes', construindo parentesco e laços conjugais através da oferta e solicitação de comida que criava experiências agradáveis". Vemos assim que entre os Tupinambá de Olivença a transformação de brancos em índios pode se dar concomitantemente em gerações adjacentes (indicando, possivelmente, que a coprocriação tem um papel central nesse processo; cf. VIEGAS, 2007).

Josielli Spenassato (2016), por sua vez, menciona que na Terra Indígena São Jerônimo da Serra (PR), habitada pelos povos Kaingang, Guarani e Xetá, os filhos de uniões de homens brancos com mulheres indígenas podem se autodenominar ou ser chamados de "mestiços" (ali, a maioria das uniões mistas se dá entre homens não indígenas e mulheres 
indígenas). Não obstante, uma possível reincidência de casamentos com brancos por essas pessoas "mestiças" não leva seus filhos a serem considerados mais mestiços, ou mais brancos. Afinal, mesmo os "mestiços" podem por vezes se identificar inequivocamente pelo povo de um de seus pais (por exemplo, uma mulher "mestiça" pode se afirmar "guarani"; cf. SPENASSATO, 2016, p. 109).

Como demonstra Spenassato (2016), há nesta Terra Indígena uma dupla tendência: de um lado, a afirmação de que todos os residentes são "misturados", ressaltando a semelhança entre pessoas guarani, kaingang e xetá; de outro, a separação das parentelas em "lados" determinados pela política, em que ressaltam singularidades e particularidades sob a liderança dos caciques guarani, kaingang e xetá. A autora revela um complexo jogo por trás da filiação aos "lados": pessoas guarani, por exemplo, podem decidir participar do "lado" kaingang, sobretudo quando seus cônjuges são kaingang (cf. SPENASSATO, 2016, p. 173). Dessa maneira, a identificação política em São Jerônimo da Serra pode ser contextualmente alterada.

$\mathrm{Na}$ imensa maioria dos casamentos entre índios e não índios, os brancos são levados a viver nas aldeias. Com isso, passam a integrar o "lado" político de suas esposas (SPENASSATO, 2016, p. 175). Incluídos no parentesco, estabelecem com os indígenas as "relações as mais fundamentais" (SPENASSATO, 2016, p. 147), baseadas na convivialidade, na comensalidade, etc. Todavia, os brancos jamais "viram completamente indígenas" (SPENASSATO, 2016, p. 147), e chegou a haver uma deliberação na aldeia impedindo os brancos de envolverem-se "nas questões políticas da aldeia", "em qualquer desavença ou conflito interno", ou em disputas por cargos de liderança (SPENASSATO, 2016, p. 145). Os indígenas chegaram a tentar proibir os casamentos com brancos, ainda que tal norma tenha surtido pouco efeito (SPENASSATO, 2016, p. 145).

Também entre os Mbya de Camboinhas, aldeia já extinta, havia casamentos com não indígenas (cf. MIGLIORA, 2014; PEREIRA, 2017). Como demonstra Amanda Migliora (2014), esses indígenas se casavam apenas com os brancos que viviam perto, participando constantemente dos forrós e jogos de futebol na aldeia. De acordo com Vicente Pereira (2017), que realizou pesquisa de campo no mesmo local, os Mbya procuram "amansar" seus cônjuges brancos como fazem com os xerimbabos. Assim, os indígenas buscam "causar alegria" e "fazer acostumar" (-mbovya) o xerimbabo e o branco, por meio de cuidados cotidianos que inculcam no outro uma moralidade mbya. Segundo o autor, essa modalidade de ação revela "a possibilidade de aproximar corpos de brancos a corpos de mbya" (PEREIRA, 2017, p. 73; grifos suprimidos). Mesmo assim, os cônjuges brancos jamais são tornados completamente mbya, como atestam tanto Pereira (2017) quanto Migliora (2014, p. 88). Não obstante, Migliora (2014, p. 88) sugere que os filhos das uniões mistas são inequivocamente indígenas: neste exemplo, os casamentos levam à domesticação dos brancos (apesar de não transformá-los em índios) e colocam em funcionamento uma máquina de produção de pessoas inequivocamente mbya a partir de pessoas brancas. 
Ainda que todos os exemplos apontados acima coloquem em cena casamentos entre índios e brancos, a domesticação de não indígenas não necessariamente envolve matrimônios. Márnio Teixeira-Pinto (2002, p. 418), por exemplo, demonstra a incorporação dos brancos às redes de troca e ao sistema de cooperação mútua arara, através de uma imposição dos "comportamentos não-egoístas, a reciprocidade, a generosidade" aos brancos. Segundo o autor, isso indicaria a possibilidade de "subordinação [dos brancos] à lógica nativa da solidariedade, da cooperação e da generosidade" e de "incorporação" dos não índios à "sociedade arara" (TEIXEIRA-PINTO, 2002, p. 418). De modo análogo, José Kelly (2005) demonstra as tentativas yanomami de inculcar a moralidade indígena nos brancos, visando a produção deliberada de similaridade entre pessoas yanomami (indígenas) e napë (não indígenas), contra a diferença dada e pretérita que as separa. Para tanto, os Yanomami instam os não indígenas a aprender sua língua e a usar os termos de parentesco apropriados. Além disso, os esforços indígenas de "domesticação" não se restringem às pessoas brancas, podendo ser estendidos aos objetos não indígenas algo encontrado no Alto Rio Negro (cf. ANDRELLO, 2006; 2008), entre os Waiwai (HOWARD, 2002), entre os Wayana (VAN VELTHEM, 2002), entre os Aparai e Wayana (BARBOSA, 2009) e entre os Kawaiwete (OAKDALE, 2008).

Se há tentativas de "domesticar" brancos sem com eles contrair casamento, é digno de nota que o matrimônio e a coprocriação são as formas por excelência de reduzir, ou extrair, a alteridade dos brancos. Pois a domesticação dos brancos se caracteriza precisamente pelas tentativas de um sujeito (agente) em causar uma transformação em um objeto (paciente) ${ }^{6}$ através dos mecanismos de assemelhamento corporal que integram aquilo que convencionalmente chamamos de "parentesco". Trata-se, em linhas gerais, de procedimentos para alotransformação, que visam a diminuição da alteridade de determinados brancos por meio da redução intencional de sua afinidade constitutiva. Neste sentido, a domesticação dos brancos está em compasso com a "produção do parentesco", tendo o mesmo sentido do eclipsamento da afinidade (cf. VIVEIROS DE CASTRO, 2002; VILAÇA, 2005). É, em resumo, uma tentativa de transformar brancos em parentes e de fazer novos parentes a partir deles (cf. VILAÇA, 2002), estendendo os procedimentos de assemelhamento corporal para pessoas com quem casamentos não eram usualmente realizados. Caracteriza-se, dessa maneira, como uma extensão analógica dos procedimentos por trás dos casamentos com estrangeiros e inimigos indígenas.

Mas há, evidentemente, perigos por trás dessas operações. Como notamos, a diferença dos brancos sempre se impõe, jamais tornando-se completamente inerte - como, aliás, é sempre o caso nas terras baixas sul-americanas, mesmo em casamentos entre indígenas social e geograficamente próximos. Além disso, há sempre a chance de que o vetor da transformação se inverta, i.e., que sejam os índios a se

\footnotetext{
${ }^{6}$ A distinção proposta por Strathern (1988) entre "agente" e "pessoa" também parece ser interessante para pensar essa diferença entre sujeito e objeto da domesticação. Pretendo discuti-la em outra ocasião.
} 
transformarem em brancos pelo casamento (uma consequência diretamente relacionada ao "virar branco"). Pois como ressaltam alguns autores (cf. sobretudo MAINARDI, 2015 para os Tupi Guarani e HOWARD, 2001 para os Waiwai), as transformações sempre são mútuas, e o agente da domesticação é sempre afetado pelo paciente da transformação (cf. também FAUSTO, 2008).

\section{Digital e analógico}

A possibilidade de que brancos se tornem parentes, e com isso sejam reclassificados como "índios", parece impor uma espécie de paradoxo. Afinal, abundam nas terras baixas sul-americanas descrições que ressaltam a diferença radical e convencional entre brancos e índios, entendida como uma distinção digital separando duas formas de humanidade - ou, ainda, uma "humanidade" e uma "não-humanidade". Esse tema está presente em diversos mitos de origem dos brancos. Foi notado no episódio do arco e da espingarda, no qual um demiurgo oferece aos ancestrais de índios e brancos a possibilidade de escolherem entre o arco e a espingarda. Por uma má escolha, os índios escolhem o arco e, os brancos a espingarda, inaugurando diferenças tecnológicas e morais entre índios e não índios. Com isso, os brancos tornam-se tecnicamente superiores, porém moralmente inferiores em relação aos índios. Este episódio é encontrado entre diversos povos do Alto Rio Negro (cf. HUGH-JONES, 1988 para os Barasana, BUCHILLET 2002, p. 130 para os Desana; LASMAR, 2005, p. 150 para os Tukano; ANDRELLO, 2006 para os Tariano), entre os Waimiri-Atroari (BAINES, 2002, p. 316) e também entre os Wajãpi (GALLOIS, 2002, p. 219). Segundo Viveiros de Castro (2000) e Lasmar (2005), esse episódio tem claras afinidades com o tema da origem da vida breve, indicando ainda que o surgimento dos brancos é diretamente associado à origem da morte (cf. VIVEIROS DE CASTRO, 2000).

A separação digital entre duas humanidades distintas também é notada em outros mitos de origem dos brancos. Poderíamos citar as narrativas Timbira (DAMATTA, 1970) e Parakanã (FAUSTO, 2001), nas quais os brancos surgem de uma criança mágica, filha de uma mulher indígena e de um rato. Após uma série de desventuras, os parentes indígenas abandonam a criança poderosa e acabam desprovidos de suas capacidades mágicas, das quais os brancos são herdeiros diretos. Essas versões guardam analogias evidentes com a narrativa dos Tupi quinhentistas, para quem a divisão entre brancos e índios também resulta de uma escolha equivocada dos últimos, que decidem (assim como na narrativa timbira) queimar o demiurgo Maire-Monan, cujos "filhos verdadeiros" (os brancos) recebem bens culturais dos quais os índios acabam privados (cf. LÉVI-STRAUSS, 1991). Encontramos uma transformação contemporânea dessa versão entre os Mbya, também colocando em cena a origem dos brancos (cf. PIERRI, 2013).

Os termos utilizados pelos índios para chamarem e se referirem aos brancos indicam uma separação análoga. Em alguns povos, os brancos 
são chamados por termos distintos daqueles usados para os inimigos e estrangeiros "tradicionais". Este é o caso dos Mbya, para quem o termo jurua, usado em referência aos pelos faciais dos não indígenas, não é utilizado para categorizar nenhum outro ser (cf. MACEDO, 2009). Já entre os Aweti, os brancos são chamados de carai'wa (como entre os outros povos do Alto Xingu; cf. MENGET, 2001), termo distinto de mo'at ("xinguano", ou ainda "humano/antropomorfo") e também de waraju (que significa os índios não xinguanos) (VANZOLINI, 2015). Em outros povos, os brancos foram primeiramente chamados de termos que significam "inimigos": nos Parakanã, onde posteriormente os brancos receberam um termo específico (antes akwawa, passaram a ser chamados de toria) (FAUSTO, 2001), e nos Mebêngôkre, onde o termo kuben, "inimigo", tornou-se com o tempo exclusivo aos não indígenas (quando não utilizado com nenhuma outra qualificação) (LEA, 2012).

A meu ver, mitos e termos de referência indicam uma mesma característica: o largo abismo separando brancos e índios enquanto duas humanidades apartadas e radicalmente distintas (BRUSCO, 2018, p. 5661 para uma discussão mais aprofundada). Com efeito, após invadirem as Américas, os não indígenas tornaram-se a expressão mais bem acabada da alteridade, passando a figurar como inimigos por excelência em cosmologias de muitos povos. Não à toa, diversos autores indicam que o maior contraste concebido pelo pensamento indígena é precisamente aquele entre brancos e índios (cf. LÉVI-STRAUSS, 1991; FRANCHETTO, 1993 para os Kuikuro, TURNER, 1993 para os Mebêngôkre; VAN VELTHEM, 2002 para os Wayana; OAKDALE, 2008 para os Kawaiwete). Como afirma Taylor (2015, p. 154), "se a ordem colonial consagrou a dissolução das práticas guerreiras que alimentavam a relação com o Outro, ela até agora não fez desaparecer a perspectiva do Inimigo, um papel hoje destinado aos Brancos - e que eles desempenham muito bem".

O largo abismo digital separando brancos e índios é que sustenta as teorias do "virar branco" disseminadas na etnografia especializada, comparadas por Kelly (2016) em seu trabalho recente. É porque "branco" e "índio" são dois conjuntos mutuamente exclusivos de qualidades e capacidades genéricas que podem significar a fração interna à pessoa "misturada" - conceitualizada como metade indígena, metade branca. Dessa maneira, essas duas posições, contidas no interior da pessoa e pensadas enquanto dois pontos de vistas (o de Eu e o de Outro), não seriam suscetíveis à fusão, só podendo ser elicitadas, eclipsadas, combinadas ou contrapostas em relação (COELHO DE SOUZA, 2017, p. 207, sobre o trabalho de KELLY, 2016).

Como, então, podem os brancos tornarem-se parentes e, eventualmente, indígenas, como viemos demonstrando? Parece, de fato, que a domesticação dos brancos sobre a qual venho escrevendo oferece outra forma de conceitualizar as distinções entre índios e não índios nas terras baixas sul-americanas. Em suma, a possibilidade de que não índios tornem-se índios mediante o parentesco aponta para o fato de que os indígenas das terras baixas sul-americanas classificam pessoas como 
"mais índias", "menos índias", "mais brancas" e "menos brancas". Vejamos como isso é descrito em algumas etnografias.

A análise de Cristiane Lasmar (2005) indica que os habitantes indígenas de São Gabriel de Cachoeira distinguem os brancos locais quanto à sua origem e tempo de residência na cidade. Essa forma de classificação também incide sobre os próprios índios, em especial quanto ao local de sua habitação, a "comunidade" ou a "cidade". No último espaço, há ainda distinções entre indígenas segundo o tempo que vivem no meio urbano: as mulheres indígenas nascidas em São Gabriel da Cachoeira (autodenominadas "moças da Praia") costumam se referir às jovens recém-chegadas da comunidade como "meninas do sítio", indicando que são mais manipuláveis pelos brancos e mais propensas a sofrer violência sexual (LASMAR, 2005, p. 184). Assim, os índios nascidos na cidade estariam mais próximos ao modo de viver branco, enquanto aqueles que vivem nas comunidades, ou dali migraram recentemente, se encontrariam mais distantes da vida dos brancos. Essa diferença é marcada nos corpos, refletindo "o contraste entre um corpo talhado para a atividade da roça e a vida na comunidade e outro mais afeito à vida urbana" (LASMAR, 2005, p. 187) e indicando ainda uma "dimensão processual da identidade" (LASMAR, 2005, p. 191). De acordo com o trabalho de Cristiane Lasmar, é possível identificar uma gradação do "mais branco" ao "mais índio" em São Gabriel da Cachoeira, na qual a identidade das pessoas é definida por meio das capacidades de seus corpos, entendidos enquanto feixes de afecções (cf. LASMAR, 2005, p. 196 e VIVEIROS DE CASTRO, 2002 para a expressão).

A dissertação de Camila Mainardi (2010) demonstra entre os Tupi Guarani de Piaçaguera uma forma de classificação análoga. Segundo a autora, os Tupi Guarani se distinguem de seus vizinhos mbya por serem "menos índios", ou "mais brancos". Como sua tese de doutorado permite entrever (MAINARDI, 2015), essa forma de classificação também está intimamente relacionada aos corpos - os Tupi Guarani, mais habituados, graças à "mistura", ao modo de vida dos brancos, teriam corpos mais parecidos aos corpos não indígenas. Notemos que os próprios Mbya também afirmam essa diferença corporal em relação aos Tupi Guarani, muito devida à "mistura" destes com os brancos (MACEDO, 2017; BRUSCO, 2017 para uma discussão comparativa deste contraste).

Havíamos apontado que os Potiguara distinguem os não indígenas em algumas categorias. Essas diferenças são também internas aos índios: segundo José Glebson Vieira (2010, p. 146), as pessoas podem ser consideradas mais ou menos caboclas a depender de seus comportamentos e de seus antepassados - ou seja, uma pessoa pode ser considerada "menos cabocla" por ter um ascendente não indígena, por exemplo. Esse tipo de classificação é também temporal: os Potiguara distinguem-se de seus antepassados por serem "menos selvagens", remetendo a transformações corporais que, causadas pelo batismo, pelo casamento e pela procriação, puseram fim à braveza e à pureza de sangue característica do passado selvagem (VIEIRA, 2010, p. 107). Em sentido tanto espacial quanto temporal, notamos uma classificação gradativa e 
cromática, baseada nas diferenças corporais, que separa a "selvageria" da "civilização" - indo do "mais caboclo" ao "menos caboclo".

Também entre os Arapiuns da região de Santarém (PA) podemos observar algo semelhante. Segundo Mahalem de Lima (2015, p. 177-9), esses indígenas descrevem um contínuo que vai do branco ao índio. Os Arapiuns consideram ocupar uma posição intermediária: diferenciam-se tanto dos brancos quanto dos "índios selvagens", pois comem peixe assado e cozido (ao contrário do que fariam brancos e selvagens). Os Arapiuns consideram-se, assim, "índios misturados", a meio caminho na escala cromática que separa as posições polares de "índio bravo" e "branco" (MAHALEM DE LIMA, 2015, p. 181). Como revelam esses indígenas, as diferenças incidem sobretudo nos "jeitos de ser", e mesmo o centro do espaço classificatório, ocupado pelos Arapiuns, também é povoado por distintas "classes de pessoas" (MAHALEM DE LIMA, 2015, p. 181). Segundo Mahalem de Lima (2017), isso explica o constante "trânsito posicional" registrado pelo autor (i.e., a possibilidade de mudança contextual na classificação de si e de outros).

Segundo Fernando Fileno (2017, p. 163), também há entre os Mura um eixo levando do "índio bravo" ao "branco". Nas palavras do autor, "essas duas categorias apresentam um contínuo de diferenças que discernem sobre o contraste entre a selvageria do interior da mata e a civilidade urbana" (FILENO, 2017, p. 163). Face a essa modalidade de classificação, os Mura se interessariam em ocupar ambas as posições. De acordo com Fileno (2017, p. 166), as diferenças entre as posições no eixo classificatório seriam notadas sobretudo pelas formas de alimentação: os índios "bravos" se alimentariam de carne de caça crua, com muito sangue, enquanto os brancos, com seus congelados, se alimentariam de comida moída e podre (sem sangue). Os Mura, assim, colocam-se no centro dessa escala classificatória, ainda que se assemelhem aos brancos por às vezes comerem na cidade e aos índios bravos por compartilharem um "ethos do caçador" (FILENO, 2017, p. 164). Mais uma vez, portanto, a diferença incide nos corpos.

Todos esses casos evocam imediatamente o exemplo Piro. Com efeito, Peter Gow (1991) parece ter sido o primeiro a dar atenção a essa lógica classificatória que opõe dois polos, cujas características são compartilhadas pelos povos que ocupam as posições intermediárias. Como outros povos do continente, os Piro dispõem-se no centro de um espaço geográfico cujos polos são ocupados pelos "índios selvagens" e pelos "gringos" (cf. GOW, 1991). Por ocuparem o centro deste espaço, compartilham algumas características tanto com os "selvagens" (sua vitalidade física e sua capacidade para o trabalho; cf. GOW, 1993, p. 335) quanto com os "gringos" (uma certa quantidade de seu conhecimento perigoso; cf. GOW, 1993, p. 335).

Outros autores revelaram um tipo de espaço de classificação semelhante àquele descrito por Gow para os Piro, como Kelly (2005) para os Yanomami e, fora das terras baixas sul-americanas, Pitarch (2013) para os Tzeltal e Course (2013) para os Mapuche (cf. KELLY 2016 para um apanhado comparativo). Os exemplos não se limitam às relações com brancos, pois encontramos nos trabalhos de Christine Hugh-Jones (1979) 
para os Barasana, de Arhem (1989) para os Makuna e de Bruno Marques (2009) para os Maku (entre outros), descrições de espaços ameríndios análogos, sem uma referência explícita aos não indígenas. Com efeito, essa modalidade de organização do espaço permitiu a Viveiros de Castro (2002) compor sua síntese acerca do parentesco amazônico: o autor sobrepõe ao diametralismo da terminologia dravidiana uma classificação cromática e analógica, de ordem socioespacial e também genealógica, que opõe o cognato ao não-cognato.

Essa modalidade de classificação, notada por Viveiros de Castro (2002), aplica-se aos brancos em diversos exemplos. Entre dois polos separando brancos prototípicos e índios selvagens, há espaço para uma série de "tipos de gente" que podem se assemelhar mais, ou menos, à população que preenche a posição intermediária (ocupada, usualmente, pelo sujeito do enunciado). Neste sentido, uma imensa quantidade de não indígenas, com corpos distintos e trajetórias diferentes, são posicionados em diferentes pontos dessa escala, podendo ser considerados mais ou menos próximos aos indígenas. Uma vez que o corpo, nas terras baixas sul-americanas, pode ser constantemente fabricado e transformado, definindo o ponto de vista do sujeito e, consequentemente, sua posição nessas diferentes versões de escalas analógicas classificatórias, há sempre a possibilidade de que a alteridade constitutiva dos brancos seja gradativamente diminuída através dos procedimentos de aparentamento. Em suma, é possível fazer parentesco com não indígenas a partir de práticas que visem transformá-los em índios (ou "menos brancos"), intencionalmente fabricando proximidade com eles a despeito da imensa diferença que separa brancos e índios (enquanto duas posições polares e excludentes). Desse modo, as múltiplas histórias de casamentos com brancos frequentemente referem-se a reclassificações de sujeitos não indígenas através dessas escalas analógicas.

A pertinência desse modelo de classificação não exclui a oposição diametral entre brancos e índios, sobre a qual tratávamos acima. É preciso sublinhar a coexistência dessas duas formas de dualismo nas terras baixas sul-americanas: um contraste digital e de grande intervalo opondo exclusivamente brancos e índios (enquanto duas formas de humanidades apartadas) e uma escala analógico-cromática separando, em curtos intervalos, diferentes tipos de indígenas e de não indígenas e sobre a qual se dão infindáveis deslocamentos e alterações contextuais. Essas formas de classificação remetem diretamente às discussões de Lévi-Strauss sobre dualismos nas organizações sociais (cf. LÉVI-STRAUSS, [1956] 2003) e na mitologia (cf. LÉVI-STRAUSS, 1991) da região das terras baixas. Essa coexistência de duas formas de classificação também foi notada por Kelly (2016), ainda que o autor não tenha incluído em sua síntese a domesticação dos brancos (ao contrário do que fez em KELLY, 2005).

\section{Outras sínteses}

Como viemos notando, a domesticação dos brancos é um caso do amansamento de inimigos e estrangeiros indígenas. Há ao menos dois 
autores que se voltaram ao último fenômeno de um ponto de vista comparativo: Carlos Fausto $(2001 ; 2008)$ e Fernando Santos-Granero (2009). Por essa razão, discuto a seguir seus trabalhos, ressaltando, contudo, alguns limites no uso de seus conceitos para o material apresentado neste artigo.

Sobretudo em sua monografia sobre os Parakanã, Carlos Fausto (2001) propôs um modelo para a elucidação comparativa da guerra e do xamanismo na Amazônia. Segundo o autor, as ações guerreiras e xamânicas na região caracterizar-se-iam pela alternância dialética entre "predação" e "familiarização" (FAUSTO, 2001, p. 418). De modo geral, a predação seria o procedimento de apropriação de potências e capacidades alheias, usualmente pela destruição de pessoas na guerra, resultando na transformação ontológica do matador graças à sua identificação à vítima (FAUSTO, 2001, p. 442). Segundo Fausto (2001, p. 463) este processo deve ser acompanhado de sua contraparte, a familiarização. Em linhas gerais, as capacidades absorvidas pelo matador em virtude de sua fusão com o inimigo morto devem ser domesticadas, amansadas, "degradadas", para que assim possam ser estendidas e socializadas ao restante do grupo. Caso a potência estrangeira do inimigo não fosse "familiarizada", haveria o risco de uma identificação excessiva entre matador e vítima, podendo levar à transformação completa do matador em outro (FAUSTO, 2001, p. 463).

De acordo com Fausto (2001, p. 413), a passagem de uma relação de predação àquela de familiarização seria homóloga à "passagem da afinidade à consanguinidade". Em suma, a apropriação das capacidades de afins distantes (potenciais) implicaria a transformação do inimigo (ou, mais precisamente, de seu espírito) em "xerimbabo" ou "filho adotivo", dando ensejo a "relações assimétricas de controle, real ou simbólico, conceitualizadas como uma forma de adoção" (FAUSTO, 2001, p. 413). Seriam essas relações de controle e cuidado que permitiriam a socialização dos efeitos da predação: a alteração ontológica do matador poderia ser assim estendida a seus parentes, transformando a destruição de uma pessoa (pela predação) na produção de pessoas (pela extensão dos efeitos da predação mediante a familiarização). A continuidade do processo dependeria da realização de outros atos predatórios que reiniciariam o ciclo: é a sequência predação-familiarização-predação que caracteriza o conceito de "predação familiarizante" proposto pelo autor (FAUSTO, 2001, p. 456-8).

Posteriormente, Fausto (2008) procurou relacionar seu modelo da predação familiarizante às figuras dos "donos", existentes por todas as terras baixas sul-americanas, sugerindo que o esquema das relações de domínio basear-se-ia ora na domesticação de animais de estimação, ora na adoção de crianças. De acordo com o autor, as relações de domínio estão disseminadas por diversos planos: estariam presentes nas figuras dos mestres de caça, na posse de certos bens (materiais e imateriais), nas relações entre matadores e vítimas após o homicídio, nas relações com animais de estimação, naquelas entre chefe e seguidores e também nas relações entre pais e filhos adotivos estrangeiros (FAUSTO, 2008, p. 333). Segundo Fausto (2008, p. 333), as relações entre esses donos e suas 
criaturas seriam marcadas na região como relações assimétricas entre consanguíneos, tendo a "filiação adotiva" como seu modelo principal. "Assimetria", segundo o autor, significa tanto controle quanto proteção, indicando a possibilidade de amansamento de um filho-xerimbabo sem torna-lo completamente "manso" - afinal, é justamente a alteridade do ente domesticado que permite a um "dono" se magnificar (i.e., se particularizar por conter em si singularidades outras) (FAUSTO, 2008, p. 343). Vemos assim que o amansamento dos filhos-xerimbabo se efetua mediante a relação de "familiarização" desdobrada anteriormente por Fausto (2001).

Para nossos propósitos, é fundamental ressaltar a sugestão de Fausto (2008, p. 347) segundo a qual a relação de maestria é "relevante para a análise das relações assimétricas entre povos indígenas". Nas palavras do autor, "sugiro que tenha sido um dispositivo sociológico bastante importante no passado, servindo à estruturação de relações hierárquicas entre diferentes grupos indígenas, algo que pode se observar ainda hoje em alguns sistemas regionais" (FAUSTO, 2008, p. 347). Desse modo, a discussão de Fausto apontaria que os exemplos aos quais voltamo-nos neste capítulo poderiam ser interpretados à luz do idioma do domínio, pautado nas assimetrias (e, neste caso, hierarquias) entre povos indígenas. Neste sentido, seria possível considerar o amansamento e pacificação dos brancos como mais um caso da "generalidade do idioma do dono-mestre" (FAUSTO, 2008, p. 348), sugerindo a pertinência de falarmos em "familiarização dos brancos".

A exploração comparativa de sistemas regionais pré-coloniais por Fernando Santos-Granero (2009) está intimamente ligada à proposição de Carlos Fausto (2008). Segundo Santos-Granero (2009), as relações assimétricas entre povos indígenas teriam se caracterizado, no passado, por três "regimes de servidão": a) "populações tributárias", que conservavam suas terras contanto que concordassem em pagar tributos a seus dominadores (SANTOS-GRANERO, 2009, p. 83); b) "grupos servos", situação na qual todo um povo era subjugado por outro e incorporado em um "estrato mais baixo de servos" (SANTOS-GRANERO, 2009, p. 66); c) "escravidão cativa", caracterizada pela captura de inimigos, posteriormente sacrificados ou tornados "escravos cativos". Em todos os casos, pessoas em distintos regimes de servidão poderiam ser tornadas "parentes" através de um processo que Santos-Granero (2009) cunha de "civilização do outro". Sendo assim, a suposta escravidão ameríndia se caracterizaria como um "status temporário em um processo no qual inimigos Outros são civilizados e transformados em consanguíneos íntimos" (SANTOS-GRANERO, 2009, p. 175). Em consonância com a proposta de Fausto (2008), Santos-Granero (2009, p. 174) sugere que o processo de "civilização do outro" seria uma forma de "familiarização", na qual "os cativos de guerra eram concebidos como animais domésticos".

Com efeito, ambos os autores concordam em um ponto central: os processos de familiarização ou civilização sempre implicam assimetrias (ou até mesmo hierarquias) entre os povos envolvidos. Em Fausto (2008, p. 347), relações de maestria entre povos indígenas distintos implicam a "estruturação de relações hierárquicas". Em Santos-Granero (2009, p. 99), 
o processo de civilização de inimigos estaria presente em "sistemas regionais" nos quais as "relações interétnicas de poder" seriam heterogêneas, instaurando relações de "violência e coerção". Não à toa ambos os autores (FAUSTO, 2008, p. 342; SANTOS-GRANERO, 2009, p. 126) escrevem em alguma medida contra os trabalhos de Pierre Clastres (cf. sobretudo [1974] 2012; [1978] 2011): trata-se de identificar a relação que poderia dar (e teria dado) origem a formas de poder coercitivo nas terras baixas sul-americanas.

Não é objetivo deste trabalho opinar no debate sobre a existência, ou não, de formas centralizadas de poder nas terras baixas sulamericanas ${ }^{7}$. Contudo, é preciso ressaltar que o material discutido neste capítulo não permite considerar que o amansamento de estrangeiros na região esteja sempre relacionado a formas subjacentes de poder coercitivo. Afinal, não são em todos os casos que encontramos o idioma do domínio (seja na imagística da relação senhor-xerimbabo, seja naquela da filiação adotiva) por trás da domesticação.

Não se trata, evidentemente, de recusar as metáforas do controle e da proteção para exemplos de domesticação de estrangeiros (afinal, encontramos seu uso em exemplos discutidos, como os Waiwai, os Aparai e Wayana, os Tiriyó e até mesmo na relação dos Mbya com os brancos). Considero, antes, que as supostas "assimetria" e "hierarquia" por trás da "familiarização" e da "civilização", discutidas respectivamente por Fausto (2008) e Santos-Granero (2009), não se estendem a todos os casos, de tal maneira que os exemplos discutidos pelos autores são apenas versões particulares de um fenômeno mais amplo. Dito de outro modo, nem toda domesticação de estrangeiros implica "hierarquia" ou "controle". O trabalho do próprio Carlos Fausto (2001, p. 86) o indica: conforme o autor demonstra, o verbo parakanã ocidental - mo'yng (traduzido por "pacificar") é utilizado para indicar uma "transformação daquele que sofre a ação pacificatória em direção daquele que promove a ação". Usualmente, os Parakanã ocidentais utilizam este verbo para descrever a transformação de mulheres raptadas em "parentes", "pensada como processo gradativo de adoção de novas marcas e disposições corporais, e da capacidade de comunicar-se adequadamente" (FAUSTO, 2001, p. 265). Como viemos ressaltando em todos os exemplos discutidos, também essas mulheres estrangeiras, tornadas parentes, não deixam de ser estrangeiras (akwawa), "ou mais precisamente, 'filhas de akwawa"” (FAUSTO, 2001, p. 266). Seja como for, os Parakanã não utilizam qualquer imagem de "controle" ou de "filiação adotiva" para se referirem a este processo:

Não procuravam, porém, manter as cativas apenas pelo medo. Era preciso que se sentissem novamente em casa, que "se acostumassem completamente" (-je-

\footnotetext{
${ }^{7}$ Cabe ressaltar, no entanto, que interpretações posteriores da obra de Pierre Clastres sugerem que seu principal aporte à etnologia da região não se encontraria nos grandes contrastes que o autor erige (cf. DELEUZE \& GUATTARI, [1980] 2012; SZTUTMAN 2009; PERRONE-MOISÉS \& SZTUTMAN 2010; VIVEIROS DE CASTRO 2011; VANZOLINI 2011; entre outros). Neste sentido, seria possível interpretar a concentração contextual e parcial de poder nas mãos de determinados chefes ou povos a partir dos escritos do próprio Clastres.
} 
pokwapam). Segundo contam, elas não demonstravam raiva ou revolta pela sua condição, mas choravam muito e era necessário fazê-las superar a tristeza para que se integrassem. Já no retorno da expedição, instavam-nas a permanecer: "menstruem entre nós", diziam, convencendo-as de que seriam bem tratadas: "vejam, vocês antes tinham fome, e agora nós lhe daremos caça". [...] Aceitar o alimento e comer junto com os captores era sinal de consentimento e disposição para entrar no jogo do parentesco. [...]. Os primeiros momentos de integração eram marcados pelo canto e pela dança. [...]. Através da festa incorporavam-se definitivamente as estrangeiras, desejando-se que fossem longevas e que se fixassem entre eles. Sua condição social de esposas sem irmãos transformava-se aos poucos com a chegada dos filhos e a constituição dos laços de parentesco. Algumas delas adquiriram, inclusive, certo destaque no grupo pelas histórias que contavam, pelos nomes de ex-parentes que enunciavam (e com os quais se podia nomear as crianças) ou por serem associadas ao xamanismo (FAUSTO, 2001, p. 301-2).

Peço desculpas pela longa citação, mas penso que essa descrição é relevante. Os casos de domesticação dos brancos apresentados neste artigo guardam muitas semelhanças com esta descrição: como bem demonstra Fausto (2001, p. 302), ela revela um "processo de pacificação e aparentamento", análogo, portanto, àquilo que diversos povos indígenas tentaram e ainda tentam fazer com determinados brancos. $\mathrm{E}$ apesar de Fausto (2001) dedicar grande parte de seu livro à familiarização, não menciona uma vez sequer que a "pacificação" (mo'yng) de estrangeiras seria comparada pelos Parakanã ao amansamento de animais domésticos (ou filhos adotivos) ${ }^{8}$. Neste sentido, é possível supor que o uso de imagens do domínio no amansamento de estrangeiros não seja uma regra, mas apenas um caso particular da relação de domesticação, espalhada por todas as terras baixas sulamericanas. Em suma, a domesticação é acima de tudo um processo de diluição da alteridade (cf. TAYLOR, 2015, p. 139) através de tratativas de alotransformação, que podem ou não se basearem no "controle".

\footnotetext{
${ }^{8}$ Em uma única passagem de seu livro, Fausto (2001, p. 430) relaciona a familiarização à relação com as mulheres estrangeiras incorporadas. Mesmo assim, não há qualquer referência a uma imagem da filiação adotiva ou do controle: a "familiarização" das mulheres no ritual das tabocas é comparada ao ato de matar um inimigo, sem que sejam no entanto transformadas em xerimbabos.

${ }^{9}$ Logo após terminar a escrita deste artigo, me inteirei da correspondência entre Walker (2012a, 2012b, 2013) e Fausto $(2012,2013)$, na qual um dos pontos discutidos é precisamente o caráter do "controle" em relações assimétricas de maestria. Walker (2012b, p. 688) argumenta, por exemplo, que "subjetividade e agência podem frequentemente ser ativadas através de formas de subordinação que têm mais relação com noções de responsabilidade e cuidado que com noções de controle e predação". Este debate pode certamente contribuir para a discussão aqui realizada. Sem poder discuti-lo a fundo, limito-me aqui a mencioná-lo, guardando para uma futura oportunidade a discussão sobre esta correspondência.
} 


\section{Coda}

Neste trabalho, vim condensando e simplificando uma série de reflexões que em minha dissertação de mestrado são discutidas a fundo. Não pude abordar, por exemplo, a ação recíproca entre "virar branco" e "domesticação dos brancos", que parece ser uma transformação do próprio "processo do parentesco" nas terras baixas sul-americanas (cf. VIVEIROS DE CASTRO 2002) - uma vez que, agindo como o ritual e o xamanismo, o "virar branco" repotencializa diferenças consumidas no movimento de assemelhamento corporal colocado em cena pela domesticação dos brancos. Tampouco pude abordar a complexificação deste processo por outras duas modalidades de relação que também são descritas nas etnografias - o "virar índio" e a "domesticação dos índios" (BRUSCO, 2018 , cap. 4; sensu GOW, 1991; FAUSTO, 2001; BONILLA, 2005; COELHO DE SOUZA, 2010; NUNES, 2012; CAPIBERIBE, 2014; SOARESPINTO, 2014; MAINARDI, 2015; DANAGA, 2016; GIRARDI, 2016; COSTA, $2017)$.

Para os propósitos deste trabalho, o importante a ressaltarmos é que a domesticação dos brancos, ao colocar em cena o continuum analógico que distingue uma série de tipos de gente de acordo com suas disposições corporais, demonstra que os "brancos" com quem os índios se casam não são na maior parte dos casos o "Branco" formulador de teorias com efeitos genocidas. Ou seja, esses "brancos" (assim chamados pelos índios) são usualmente aqueles povos que se identificam como "ribeirinhos", "caiçaras", "seringueiros" e mesmo "quilombolas". Isso requer que nos atentemos etnograficamente às sobreposições de ontologias distintas, mas minoritárias, engendradas por esses processos complexos de "mistura" - o que me parece ser o principal objetivo do programa de pesquisa que nos compele a formular teorias etnográficas da contramestiçagem (GOLDMAN, 2014, 2015). O que procurei fazer aqui foi elucidar que, do ponto de vista dos povos ameríndios das terras baixas sul-americanas (ao menos como retratados nas etnografias especializadas), esses processos de mistura não podem ser subsumidos à oposição molar entre "brancos" e "índios" - ponto ressaltado, em outros termos, por Marcio Goldman (2015). 


\section{Referências bibliográficas}

ALMEIDA, L R. Estar em movimento é estar vivo: territorialidade, pessoa e sonho entre famílias tupi guarani. 2016. 252 f. Tese (Doutorado em Antropologia Social). PPGAS, USP, São Paulo, SP, 2016.

AMOROSO, M. Corsários no caminho fluvial: os Mura do rio Madeira. In: CARNEIRO DA CUNHA, M. (org.). História dos índios no Brasil. São Paulo: Companhia das Letras, 1992. p. 297-310.

ANDRELLO, G. Cidade do índio: transformações e cotidiano em Iauaretê. São Paulo, Rio de Janeiro: Ed. UNESP/ISA/NUTI, 2006.

. Narradores indígenas do Rio Negro (ou antropologia "faça você mesmo"). Comunicação apresentada no $\mathbf{3 2}^{\circ}$ Encontro Nacional da Anpocs. Caxambu, 2008.

ARHEM, K. The Maku, the Makuna and the Guiana system. Ethnos, Londres, v. 54, n. 1-2, p. 5-22, 1989.

BAINES, S. O xamanismo como história. Censuras e memórias de pacificação waimiriatroari. In: ALBERT, B. e RAMOS, A. (orgs.). Pacificando o branco. São Paulo: Ed. UNESP, Imprensa Oficial de SP, 2002. p. 311-345.

BARBOSA, G. Das trocas de bens. In: GALLOIS, D. (org.). Redes de Relações nas Guianas. São Paulo: Humanitas, 2005. p. 59-111.

Os Aparai e Wayana e suas redes de intercâmbio. 2009. 228f. Tese (Doutorado em Antropologia Social). PPGAS, USP, São Paulo, SP, 2009.

BONILLA, O. O bom patrão e o inimigo voraz: predação e comércio na cosmologia paumari. Mana, Rio de Janeiro, v. 11, n. 1, p. 41-66, 2005.

BORGES, J L. O Aleph. São Paulo: Companhia das Letras, [1949] 2008.

BRUSCO, R. Sobre casamentos com índios e não índios em coletivos tupi guarani e guarani-mbya. R@U: Revista de Antropologia Social dos Alunos do PPGASUFSCAR. São Carlos, v. 9, n. 2, suplemento, p. 62-85, 2017.

BRUSCO, R. Outros parentes: casamentos com brancos nas terras baixas sulamericanas. 2018. 210f. Dissertação (Mestrado em Antropologia Social). PPGAS, USP, São Paulo, SP, 2018. 
Espaço Ameríndio

BUCHILLET, D. Contas de vidro, enfeites de branco e 'potes de malária'. Epidemologia e representações de doenças infecciosas entre os Desana do alto Rio Negro. ALBERT, B. e RAMOS, A. (orgs.). Pacificando o branco. São Paulo: Ed. UNESP, Imprensa Oficial de SP, 2002. p. 113-142.

CABALZAR, A. Filhos da Cobra de Pedra: organização social e trajetórias tuyuka no rio Tiquié (noroeste amazônico). São Paulo, Rio de Janeiro: Ed. UNESP/ISA/NUTI, 2009.

CAPIBERIBE, A. Não cutuque a cultura com vara curta: os Palikur e o projeto "Ponte entre Povos". In: CARNEIRO DA CUNHA, M. e CESARINO, P. (orgs.). Políticas culturais e povos indígenas. São Paulo: Cultura Acadêmica, 2014. p. 165-194.

CHEROBIM, M. Os índios guarani do litoral do Estado de São Paulo: análise antropológica de uma situação de contato. São Paulo: FFLCH/USP, 1986.

CLASTRES, P. A Sociedade Contra o Estado. São Paulo: Cosac Naify Portátil, [1974] 2012.

Arqueologia da violência: pesquisas de antropologia política. São Paulo: Cosac Naify, [1978] 2011.

COELHO DE SOUZA, M. A vida material das coisas intangíveis. IN: COELHO DE SOUZA, M. e COFFACI DE LIMA, E. (orgs.). Conhecimento e cultura: práticas de transformação no mundo indígena. Brasília: Athalaia, 2010. p. 97-118.

. Uma irritante duplicidade: breve nota sobre a contramestiçagem e os Kisêdjê.

R@U, São Carlos, v. 9, n. 2, p. 201-212, 2017.

COURSE, M. The clown within: becoming white and Mapuche ritual clowns. Comparative studies in Society and History, Cambridge, v. 55, n. 4, p. 771-799, 2013.

DAMATTA, R. Mito e antimito entre os Timbira. In: VÁRIOS AUTORES, Mito e linguagem social (ensaios de antropologia estrutural). Rio de Janeiro: Tempo Brasileiro, 1970.

DANAGA, A. Encontros, efeitos e afetos. Discursos de uma liderança tupi guarani. Tese (doutorado em Antropologia Social). 2016. 227f. PPGAS, UFSCAR, São Carlos, SP, 2016.

DELEUZE, G. \& GUATTARI, F. Mil Platôs, v. 5. São Paulo: Ed. 34, [1980] 2012.

FAUSTO, C. Inimigos fiéis: história guerra e xamanismo na Amazônia. São Paulo: Edusp, 2001. 
. Donos demais: maestria e domínio na Amazônia. Mana, Rio de Janeiro, v. 14, n. 2, p. 280-324, 2008.

Comment. Masters in Amazonia: Harry Walker's 'Demonic trade: debt, materiality and agency in Amazonia. Journal of the Royal Anthropological Institute, Oxford, v. 18, n.3, p. 684-686, 2012.

Comment. Feeding and being fed: reply to Walker. Journal of the Royal Anthropological Institute, Oxford, v. 19, n. 1, p. 170-178, 2013.

FILENO, F. No seio do rio: linhas que casam, que curam e que dançam. Parentesco e corporalidade entre os Mura do Igapó-Açu. 2017. 271f. Dissertação (Mestrado em Antropologia Social). PPGAS, USP, São Paulo, SP, 2017.

FRANCHETTO, B. A Celebração da História nos Discursos Cerimoniais Kuikuro (Alto Xingu). In: VIVEIROS DE CASTRO, E. \& CARNEIRO DA CUNHA, M. (orgs.). Amazônia: Etnologia e História Indígena. São Paulo: NHII, FAPESP, 1993. p. 95-116.

GALLOIS, D. O Movimento na cosmologia waiãpi: criação, expansão e transformação do universo. 1988. 417f. Tese (Doutorado em Antropologia Social). PPGAS, USP, São Paulo, SP, 1988.

. 'Nossas falas duras'. Discurso político e auto-representação Waiãpi. ALBERT, B. e RAMOS, A. (orgs.). Pacificando o branco. São Paulo: Ed. UNESP, Imprensa Oficial de SP, 2002. p. 205-233.

GOLDMAN, M. A relação afroindígena. Cadernos de Campo, São Paulo, v. 23, p. 213$222,2014$.

. 'Quinhentos anos de contato': por uma teoria etnográfica da (contra)mestiçagem.

Mana, Rio de Janeiro, v. 21, n. 3, p. 641-659, 2015.

GOW, P. Of mixed Blood: Kinship and History in Peruvian Amazonia. Oxford: Clarendon Press, 1991.

. Gringos and wild indians: images of history in Western Amazonia. L'Homme, Paris, v. 33, n. 3, p. 327-347, 1993.

. O parentesco como consciência humana: o caso dos Piro. Mana, Rio de Janeiro, v. 3, n. 2, p. 39-65, 1997. 
Espaço Ameríndio

GRUPIONI, D. Sistema e Mundo da Vida tarëno: um Jardim de Veredas que se Bifurcam na Paisagem Guianesa. 2002. Tese (Doutorado em Antropologia Social). PPGAS, USP, São Paulo, SP, 2002.

HOWARD, C. Wrought Identities: the Waiwai Expeditions in search of the "Unseen tribes". 2001. Tese (Doutorado em Antropologia Social). University of Chicago, Chicago, 2001.

A domesticação das mercadorias: estratégias Waiwai. ALBERT, B. e RAMOS, A. (orgs.). Pacificando o branco. São Paulo: Ed. UNESP, Imprensa Oficial de SP, 2002, p. $25-60$.

HUGH-JONES, C. From the Milk River: Spatial and Temporal Processes in North-West Amazonia. Cambridge: Cambridge University Press, 1979.

HUGH-JONES, S. The gun and the bow: Myths of White Man and Indians. L'Homme, Paris, v. 106-107, p. 138-155, 1988.

JACKSON, J. The Fish People. Cambridge: Cambridge University Press, 1983.

KELLY, J. Notas para uma teoria do 'virar branco'. Mana, Rio de Janeiro, v. 11, n. 1, p. 201-234, 2005.

. About antimestizaje. Florianópolis: Cultura e Barbárie, 2016.

LASMAR, C. De volta ao Lago de Leite: gênero e transformação no Alto Rio Negro. São Paulo, Rio de Janeiro: Ed. UNESP/ISA/NUTI, 2005.

LEA, V. Riquezas intangíveis de Pessoas Partíveis. São Paulo: EdUSP, 2012.

LÉRY, J. História de uma viagem feita à Terra do Brasil, também chamada América. Rio de Janeiro: Fundação Darcy Ribeiro, [1559] 2009.

LÉVI-STRAUSS, C. Anthropologie structurale. Paris: Plon, [1955] 2003.

O Cru e o Cozido. São Paulo: Cosac Naify, [1964] 2004.

Histoire de Linx. Paris: Plon, 1991.

MACEDO, V. Nexos da diferença: Cultura e afecção em uma aldeia guarani da Serra do Mar. 2009. 331 f. Tese (Doutorado em Antropologia Social). PPGAS, USP, São Paulo, SP, 2009. 
Misturar e circular em modulações guarani. Uma etiologia das (in)disposições. Mana, Rio de Janeiro, v. 23, n. 3, p. 511-543, 2017.

MAHALEM DE LIMA, L. No Arapiuns, entre verdadeiros e -ranas: sobre os espaços, as lógicas, as organizações e os movimentos do politico. 2015. 439f. Tese (Doutorado em Antropologia Social). PPGAS, USP, São Paulo, SP, 2015.

MAINARDI, C. Construindo proximidades e distanciamentos: Etnografia Tupi Guarani da Terra Indígena Piaçaguera/SP. 2010. 98f. Dissertação (Mestrado em Antropologia Social). PPGAS, UFSCAR, São Carlos, SP, 2010.

Desfazer e refazer coletivos. O movimento tupi guarani. 2015. 200f. Tese (Doutorado em Antropologia Social). PPGAS, USP, São Paulo, SP, 2015.

MARQUES, B. Figuras do Movimento: os Hupda na literatura etnológica do Alto Rio Negro. 2009. 209f. Dissertação (Mestrado em Antropologia Social). PPGAS, MN, UFRJ, Rio de Janeiro, RJ, 2009.

MENGET, P. Em Nome dos Outros: Classificação das Relações Sociais entre os Txicáo do Alto Xingu. Lisboa: Museu Nacional de Etnologia/ Assírio \& Alvim, 2001.

MIGLIORA, A. Inventando outros: desdobramentos de um contato multifacetado. 2014. 164f. Dissertação (Mestrado em Antropologia Social). Rio de Janeiro: PPGAS/MN, 2014.

NUNES, E. No asfalto não se pesca: parentesco, mistura e transformação entre os Karajá de Buridina (Aruanã - GO). 2012. 425f. Dissertação (Mestrado em Antropologia Social). PPGAS, UnB, Brasília, DF, 2012.

OAKDALE, S. The commensality of 'contact', 'pacification' and inter-ethnic relations in the amazon: Kayabi autobiographical perspectives. Journal of the Royal Anthropological Institute, Oxford, v. 14, n. 4, p. 791-807, 2008.

PEDREIRA, H. Os Pataxó Hã hã hãe e o problema da diferença. 2017. 179f. Dissertação (Mestrado em Antropologia Social). PPGAS, USP, São Paulo, SP, 2017.

PEREIRA, V. Nos transformamos em brancos: notas sobre a cosmopolítica mbya guarani. Nanduty, Dourados, v. 5, n. 6, p. 53-79, 2017.

PERRONE-MOISÉS, B. \& SZTUTMAN, R. Notícias de uma certa confederação tamoio. Mana, Rio de Janeiro, v. 16, n. 2, p. 401-433, 2010. 
PIERRI, D. O perecível e o imperecível: lógica do sensível e corporalidade no pensamento guarani-mbya. 2013. 277f. Dissertação (Mestrado em Antropologia Social). PPGAS, USP, São Paulo, SP, 2013.

PISSOLATO, E. A duração da pessoa. Mobilidade, xamanismo e parentesco mbya (guarani). 2006. 446f. Tese (Doutorado em Antropologia Social). PPGAS, MN, URFJ, Rio de Janeiro, RJ, 2006.

PITARCH, P. La cara oculta del pliegue: ensayos de antropología indígena. México D.F.: Conaculta, 2013.

SANTOS-GRANERO, F. Vital enemies: slavery, predation and the Amerindian Political Economy of Life. Austin: University of Texas Press, 2009.

SCHADEN, E. Aspectos fundamentais da cultura guarani. São Paulo: EDUSP, [1954] 1974.

SOARES-PINTO, N. Sobre alguns modos de usar a cultura dos Outros. In: CARNEIRO DA CUNHA, M. \& CESARINO, P. (orgs.). Políticas culturais e povos indígenas. São Paulo: Cultura Acadêmica, 2014. p. 257-286.

SPENASSATO, J. Os lados da mistura: desafios da coabitação e dos intercasamentos na Terra Indígena São Jerônimo (PR/Brasil). 2016. 203f. Dissertação (Mestrado em Antropologia). PPGA, UFPR, Curitiba, PR, 2016.

STRATHERN, M. The gender of the gift. Berkeley e Los Angeles: University of California Press, 1988.

SZTUTMAN, R. Religião nômade ou germe do Estado? Pierre e Hélène Clastres e a vertigem tupi. Novos Estudos, São Paulo, n. 83, p. 129-157, 2009.

O profeta e o principal: a ação política ameríndia e seus personagens. São Paulo: EdUSP, Fapesp, 2012.

TASSINARI, A. No bom da festa: o processo de construção cultural das famílias karipuna do Amapá. São Paulo: EdUSP, 2003.

TAYLOR, A-C. Amitiés amazoniennes: Deux contre l'Un?. Terrain, Paris, v. 65, p. 138$157,2015$.

TEIXEIRA-PINTO, M. História e cosmologia de um contato. A atração dos Arara. In: ALBERT, B. e RAMOS, A. (orgs.). Pacificando o branco. São Paulo: Ed. UNESP, Imprensa Oficial de SP, 2002. p. 405-423. 
Espaço Ameríndio

VAN VELTHEM, L. 'Feitos por inimigos'. Os brancos e seus bens nas representações Wayana do contato. In: ALBERT, B. e RAMOS, A. (orgs.). Pacificando o branco. São Paulo: Ed. UNESP, Imprensa Oficial de SP, 2002. p. 61-84.

VANZOLINI, M. Eleições na aldeia ou o Alto Xingu contra o Estado?. Anuário Antropológico, Brasília, v. 2010-1, p. 31-54, 2011.

. A Flecha do Ciúme: o parentesco e seu avesso segundo os Aweti do Alto Xingu. São Paulo: Terceiro Nome/ FAPESP, 2015.

VIEGAS, S. Terra calada: os Tupinambá na Mata Atlântica do Sul da Bahia. Rio de Janeiro: 7Letras, 2007.

.. Pleasures that differentiate: transformational bodies among the Tupinamba of

Olivença (Atlantic Coast, Brazil). Journal of the Royal Anthropological Institute, Oxford, v. 18, n. 3, p. 536-553, 2012.

VIEIRA, J G. Amigos e competidores: política faccional e feitiçaria nos Potiguara da Paraíba. 2010. 366f. Tese (Doutorado em Antropologia Social). PPGAS, USP, São Paulo, SP, 2010.

VILAÇA, A. O que significa tornar-se outro? Xamanismo e contato interétnico na Amazônia. Revista Brasileira de Ciências Sociais, São Paulo, v. 15, n. 44, p. 56-72, 2000 .

Making kin out of others in Amazonia. Journal of the Royal Anthropological Institute, Oxford, v. 8, n. 2, p. 347-365, 2002.

Chronically unstable bodies: reflections on amazonian corporalities. Journal of the Royal Anthropological Institute, Oxford, v. 11, n. 3, p. 445-464, 2005.

VIVEIROS DE CASTRO, E. Os termos da outra história. In: Instituto Socioambiental, Ms, 2000.2 Disponível em: https://pib.socioambiental.org/files/file/PIB institucional/Os termos da outra historia. pdf

A inconstância da alma selvagem e outros ensaios de antropologia. São Paulo: Cosac Naify, 2002

Posfácio: o intempestivo, ainda. In: CLASTRES, Pierre. Arqueologia da violência: pesquisas de antropologia política. São Paulo: Cosac Naify, 2011. p. 297-356.

WALKER, H. Demonic trade: debt, materiality and agency in Amazonia. Journal of the Royal Anthropological Institute, Oxford, v. 18, n. 1, p. 140-159, 2012a. 
Comment. To have a master: reply to Fausto. Journal of the Royal Anthropological Institute, Oxford, v. 18, n. 3, p. 687-689, 2012 b.

Comment. Reply to Fausto. Journal of the Royal Anthropological Institute, Oxford, v. 19, n. 1, p. 179-181, 2013.

Recebido em: 08/11/2018 * Aprovado em: 01/05/2019* Publicado em: 30/12/2019 